DE LEGA LATA

Jurnal Ilmu Hukum

FAKULTAS HUKUM UMSU
Peran dan Tanggung.Jawab Negara...(Ida Hanifah)

Volume 5 Nomor 1, Januari - Juni 2020, 10-23 DOI: https://doi.org/10.30596/dll.v5i1.3303

\title{
PERAN DAN TANGGUNG JAWAB NEGARA DALAM PERLINDUNGAN HUKUM TENAGA KERJA INDONESIA YANG BERMASALAH DI LUAR NEGERI
}

\author{
Ida Hanifah \\ Fakultas Hukum Universitas Muhammadiyah Sumatera Utara \\ Jl. Kapten Mukhtar Basri No. 3, Medan - Sumatera Utara, Indonesia \\ Telp: (061) 6622400, Fax: (061) 6623474, 6631003), Kode Pos 20238 \\ Email: idahanifah@gmail.com
}

\begin{abstract}
Abstrak
Banyak kasus hukum maupun kasus-kasus lainnya yang dialami oleh Tenaga Kerja Indonesia (TKI) di luar negeri yang sifatnya merugikan TKI tersebut. Berdasarkan fakta tersebut seharusnya Negara berperan dan bertanggungjawab penuh terhadap keselamatan dan kesejahteraan TKI itu. Peran dan tanggungjawab negara tersebut tidak hanya termaktub dalam isi undang-undang semata-mata, tetapi harus diimplementasikan dalam upaya perlindungan hukum terhadap TKI yang bekerja di luar negeri. Berdasarkan kenyataan yang ada ternyata berbagai regulasi yang ada terkait dengan perlindungan terhadap TKI diluar negeri, terdapat tumpang tindih antara satu lembaga dengan lembaga lainnya, masalah lainnya adalah bahwa kesepakatan antara Pemerintah Republik Indonesia dengan negara tujuan TKI harus sering ditinjau ulang, karena aturan-aturan negara tujuan kerap berubah sehingga TKI banyak dirugikan akibat kebijakan tersebut.
\end{abstract}

Kata kunci: Peran, Tanggung Jawab, Negara, Perlindungan, Tenaga Kerja.

\section{Abstract}

Many legal cases and other cases experienced by Indonesian Migrant Workers (TKI) abroad which are detrimental to these migrant workers. Based on these facts, the State should play a role and be fully responsible for the safety and welfare of TKI. The role and responsibility of the state is not only contained in the contents of the law solely, but must be implemented in an effort to protect the law against migrant workers who work abroad. Based on the facts, it turns out that the various regulations related to the protection of TKIs abroad, there is overlap between one institution and another, the other problem is that agreements between the Government of the Republic of Indonesia and the destination countries for migrant workers must be frequently reviewed, due to state regulations objectives often change so that many migrant workers are harmed by the policy.

Keywords: Roles, Responsibilities, State, Protection, Labor.

\section{PENDAHULUAN}

Pasal 27 ayat (2) Undang-Undang Dasar Negara Republik Indonesia Tahun 1945 menyatakan bahwa "Tiap-tiap warga negara berhak atas pekerjaan dan penghidupan yang layak bagi kemanusiaan". Berdasarkan bunyi pasal tersebut, pemerintah berkewajiban untuk memberikan atau menyediakan lapangan pekerjaan bagi rakyatnya untuk dapat hidup secara layak sesuai dengan batas-batas kemanusiaan. Fakta yang ada ternyata pemerintah belum mampu menyediakan lapangan kerja bagi rakyatnya, sehingga angka pengangguran selalu tinggi. Meskipun demikian, pemerintah memberikan kesempatan bagi warga negaranya untuk 


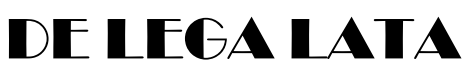

Jurnal Ilmu Hukum

FAKULTAS HUKUM UMSU
Peran dan Tanggung.Jawab Negara...(Ida Hanifah) Volume 5 Nomor 1, Januari - Juni 2020, 10-23 DOI: https://doi.org/10.30596/dll.v5i1.3303

bekerja di luar negeri, karena ketidakmampuan pemerintah menyerap tenaga kerja atau juga dikarenakan lapangan kerja yang memang minim di Indonesia.

Kebijakan untuk mengirim tenaga kerja di Indonesia, harusnya didahului dengan aturanaturan hukum untuk melindungi pekerja Indonesia yang berada di luar negeri. Sangat banyak laporan yang terdata bahwa tenaga kerja bermasalah dengan hukum, misalnya terlibat kasus pembunuhan terhadap majikan, penganiayaan yang dialami oleh TKI, gaji yang bertahun-tahun tak dibayar, penipuan oleh agen penyalur jasa tenaga kerja, pemutusan hubungan kerja sebelum masa perjanjian kerja berakhir, overstay, dan banyak problem lainnya.

Sepanjang periode Januari-Agustus 2017 ini, sebanyak 2.949 kasus telah diterima dan diproses BNP2TKI. Berdasarkan data Crisis Center BNP2TKI, apabila dilihat dari sisi tempat kejadian kasus yang dilaporkan, persebaran terbanyak masih didominasi di kawasan AsiaPasifik dan Timur Tengah. Sebagai gambaran, 10 besar negara penempatan dan yang terbanyak memperoleh pengaduan meliputi Malaysia sebanyak 994 aduan, Arab Saudi 702, Taiwan 417, Uni Emirat Arab 147, Singapura 121, Brunei Darussalam 81, Hong Kong 80, Qatar 51, serta Oman dan Bahrain masing-masing 48 kasus. Sisanya tersebar di berbagai negara tujuan penempatan dengan sebaran yang sangat bervariasi di kisaran angka 1-30-an kasus.(Ratya, melalui HYPERLINK "http://www.detikNews.com" www.detikNews.com, diakses tanggal 23 September 2018).

Berdasarkan fakta-fakta dan berbagai kondisi di atas, perlu kiranya diidentifikasi berbagai permasalahan TKI di luar negeri untuk kemudian menuntut negara dalam hal ini pemerintah mengimplementasikan peran dan memberikan perlindungan hukum bagi tenaga kerja Indonesia yang bekerja di luar negeri. Kewajiban pemerintah memberikan perlindungan hukum tersebut disebabkan pemerintak tidak mampu memberikan pekerjaan yang layak bagi warga negaranya, serta salah satu devisa negara yang termasuk besar berasal dari TKI tersebut. Perlindungan (Rahmat Ramadhani) hukum ini tentu saja akan mengarahkan kepada kepastian hukum sehingga akan memberikan rasa aman dan nyaman bagi TKI tersebut (2017, h. 143).

\section{METODE PENELITIAN}

Sesuai dengan permasalahan yang diteliti, penelitian ini merupakan penelitian hukum (legal research). Istanto, mengatakan penelitian hukum adalah penelitian yang diterapkan atau diberlakukan khusus pada ilmu hukum (Istanto, 2007: 29). Sejalan dengan Istanto, Marzuki mengatakan penelitian hukum adalah suatu proses untuk menemukan aturan hukum, prinsipprinsip hukum, maupun doktrin-doktrin hukum guna menjawab isu-isu hukum yang dihadapi (Marzuki, 2005: 35).

Jenis penelitian yang digunakan dalam penulisan ini adalah penelitian pustaka (library research). Library research berarti penelitian yang menggunakan dokumen tertulis sebagai data, dan sumber data yang digunakan dalam penelitian ini mencakup bahan hukum primer, bahan hukum sekunder dan bahan tersier. Bahan hukum primer adalah bahan hukum yang mengikat atau yang membuat orang taat hukum, meliputi produk hukum yang menjadi bahan kajian dan produk hukum sebagai alat kritiknya. Bahan hukum sekunder meliputi penjelasan bahan hukum primer berupa doktrin para ahli yang ditemukan dalam buku, jurnal, dan dalam website. 
DEIEGA LATA

Jurnal Ilmu Hukum

FAKULTAS HUKUM UMSU
Peran dan TanggungJawab Negara...(Ida Hanifah)

Volume 5 Nomor 1, Januari - Juni 2020, 10-23 DOI: https://doi.org/10.30596/dll.v5i1.3303

\section{PEMBAHASAN DAN ANALISIS}

\section{Permasalahan Tenaga Kerja Indonesia di Luar Negeri}

Masyarakat Indonesia tengah tersengat oleh Peraturan Presiden Nomor 20 Tahun 2018 tentang Penggunaan Tenaga Kerja Asing (TKA). Bagaimana tidak, jika persoalan lapangan kerja masih menjadi masalah utama bagi sebagain penduduk Indonesia. Apalagi ternyata, kesempatan kerja yang minim ini menyebabkan masyarakat menengah bawah lebih memilih untuk menjadi buruh migran. Padahal seharusnya pemerintah memberikan jaminan untuk warga negaranya untuk mendapatkan pekerjaan yang layak seperti amanat undang-undang dasar.

Terbukanya kesempatan kerja bagi tenaga kerja asing di Indonesia, sesungguhnya merupakan sebuah ironi besar, mengingat angka pengangguran yang masih sangat tinggi. Terbitnya Peraturan Presiden Nomor 20 Tahun 2018 tentang Penggunaan Tenaga Kerja Asing (TKA), sesungguhnya melukai rasa keadilan di masyarakat, meskipun alasan yang digulirkan adalah tenaga kerja asing tersebut bukanlah buruh kasar.

Kegagalan pemerintah menyediakan lapangan kerja bagi masyarakat, membuat banyak sekali warga negara yang dalam usia produktif mengadu nasib ke luar negeri untuk mencari nafkah. Pemerintah pun menyahuti keingian tersebut dengan membuka keran untuk mengirim tenaga kerja Indonesia (TKI) baik laki-laki maupun perempuan ke beberapa negara seperti ke negara-negara Timur Tengah, Asia Timur atau yang terdekat adalah ke Malaysia dan Singapura. Paling tidak dalam pengiriman TKI ke luar negeri tersebut ada 2 (dua) keuntungan yang diperoleh oleh pemerintah, yaitu mengurangi jumlah pengangguran di tanah air yang kemudian menjadi beban negara dan adanya tambahan devisa bagi negara ke luar negeri.

Keuntungan yang diperoleh negara tersebut misalnya sebagaimana Bank Dunia mencatat kontribusi remitansi (pengiriman uang dari Tenaga Kerja Indonesia/TKI ke negara asalnya) mencapai US\$8,9 miliar atau setara Rp118 triliun pada 2016 lalu. Realisasi ini setara dengan satu persen dari Produk Domestik Bruto (PDB) Indonesia. Sumbangan remitansi ini berasal dari sekitar 9 juta imigran Indonesia yang bekerja di luar Indonesia. (Fauzie, https://www.cnnindonesia.com/ekonomi/2017114247-78.258562, diakses tanggal 25 September 2018)

Berdasarkan data dari Badan Nasional Penempatan dan Perlindungan Tenaga Kerja Indonesia (BNP2TKI), sepanjang Januari sampai Agustus 2017, sebanyak 148.285 orang TKI telah ditempatkan ke sejumlah negara tujuan penempatan. Para TKI prosedural tersebut tersebar di kawasan Asia Pasifik, Amerika, Timur Tengah dan Eropa.

BNP2TKI juga mencatat negara-negara yang menjadi tempat persebaran TKI di luar negeri. Dari 26 negara yang paling banyak terdapat TKI, tercatat 10 negara terbesar untuk penempatan TKI yaitu Malaysia sebanyak 60.624 orang, Taiwan 48.737 orang, Hong Kong 9.687 orang, Singapore 11.175 orang, Saudi Arabia 10.006 orang, Brunei Darussalam 5.416 orang, Korea Selatan 4.266 orang, United Arab Emirates 1.937 orang, Oman 718 orang, dan Qatar 794 orang.

Realitasnya, persoalan buruh migran, seolah merupakan masalah yang tiada habisnya. Beragam kasus terjadi menimpa para buruh migran. Adelina Lisau hanyalah salah satu dari 


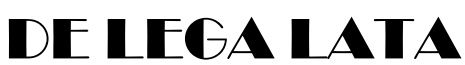

Jurnal Ilmu Hukum

FAKULTAS HUKUM UMSU
Peran dan TanggungJawab Negara...(Ida Hanifah) Volume 5 Nomor 1, Januari - Juni 2020, 10-23 DOI: https://doi.org/10.30596/dll.v5i1.3303

sekian kasus yang menimpa buruh migran. Rata-rata kasus yang menimpa buruh migran adalah kekerasan, penyiksaan, gaji tidak dibayar, dan undocumented migrant.

Jaringan Buruh Migran Indonesia (JBMI) memberikan data setidaknya ada 4.475 kasus kekerasan terhadap buruh migran sepanjang 2017. JBMI mencatat 217 Buruh migran meninggal dunia di tahun 2017. Mayoritas para pekerja tersebut meninggal di Arab Saudi, Malaysia, dan Taiwan. Sedangkan untuk kasus undocumented. Pada tahun 2017 terjadi 384 kasus. Banyak buruh migran Indonesia yang berangkat ke luar negeri dengan dokumen palsu dari calo TKI yang tidak bertanggung jawab. Meski punya dokumen lengkap pun, kadang para buruh migran mengalami kekerasan sehingga mereka terpaksa lari, sedangkan dokumen dipegang oleh majikan. (Ashleena, melalui https://www.muslimahnews.com/2018/04/16/masihkah-pemerintah-peduli-akan-nasib-buruhmigran-indonesia-2/, diakses tanggal 28 September 2018)

Data dari Crisis Center BNP2TKI sepanjang periode Januari-Agustus 2017 kasus terbanyak yang dilaporkan meliputi TKI ingin dipulangkan sebanyak 311, gaji tidak dibayar 271, TKI gagal berangkat 205, overstay 193, pemutusan hubungan kerja sebelum masa perjanjian kerja berakhir 193, sakit 186, putus hubungan komunikasi 129, pekerjaan tidak sesuai PK (perjanjian kerja) 110, perdagangan orang 68, TKI tidak berdokumen 65, potongan gaji melebihi ketentuan 65, dan lain-lain 695. (Ratya, melalui HYPERLINK "http://www.detikNews.com" www.detikNews.com, diakses tanggal 23 September 2018).

Terkait data TKI yang meninggal di luar negeri, total 145 TKI meninggal dunia selama Januari-Agustus 2017. Sebanyak 42 orang di antaranya yang bekerja di kawasan Timur Tengah serta 103 orang yang bekerja di kawasan Asia-Pasifik dan Amerika. Rata-rata penyebab meninggal adalah TKI mengalami sakit, kecelakaan kerja, kekerasan, dan lain sebagainya.

Kasus-kasus penyiksaan dan penganiayaan buruh migran merupakan fakta yang tidak bisa dihindari. Bahkan terjadi peningkatan kasus yang menimpa para buruh migran dari Indonesia. Namun, herannya, jumlah buruh migran tetap saja banyak. Khususnya di Indonesia, pengiriman TKI baik yang legal maupun illegal, terus mengalami peningkatan.

Banyaknya kasus yang dialami oleh pekerja Indonesia di luar negeri tersebut menyentak banyak pihak bahwa adakah negara hadir untuk melindungi warga negaranya yang bekerja di luar negeri. Pertanyaan seperti itu dilatarbelakangi oleh terlalu sering terjadi nasib pekerja Indonesia di luar negeri yang mendapat perlakuan tidak manusiawi. Pertanyaan lanjutannya adalah apakah perlindungan hukum yang ada dalam berbagai regulasi yang berkaitan dengan hak-hak pekerja hanya dalam ruang lingkup domestik saja atau menjangkau luar negeri juga.

Konstitusi di Indonesia sendiri telah menuangkan bahwa relasi antara negara dan warga negara sudah sangat jelas ada dan seharusnya menjadi pijakan hukum yang harus dilaksanakan oleh pemerintah sebagai sebuah kewajiban. Secara umum, kewajiban negara secara implisit ada di dalam Pembukaan UUD 1945 yakni pada alinea keempat yang menegaskan bahwa Negara berkewajiban untuk melindungi segenap bangsa Indonesia dan seluruh tumpah darah Indonesia, memajukan kesejahteraan umum, mencerdaskan kehidupan bangsa, dan melaksanakan ketertiban dunia yang berdasarkan kemerdekaan, perdamaian abadi, dan keadilan sosial. (Andryeni, dkk, 2015: 8)

Pengaturan tentang penempatan tenaga kerja Indonesia ke luar negeri adalah Undangundang No. 39 Tahun 2004 Tentang Penempatan Dan Perlindungan Tenaga Kerja Indonesia Di E-ISSN: 2477-7889 I ISSN: 2477-653XI URL: http://jurnal.umsu.ac.id/index.php/delegalata 


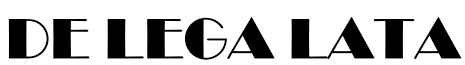

Jurnal Ilmu Hukum

FAKULTAS HUKUM UMSU
Peran dan Tanggung.Jawab Negara...(Ida Hanifah)

Volume 5 Nomor 1, Januari - Juni 2020, 10-23 DOI: https://doi.org/10.30596/dll.v5i1.3303

Luar Negeri. Pada konsideran menimbang huruf c, d dan e, disebutkan bahwa tenaga kerja Indonesia di luar negeri sering dijadikan obyek perdagangan manusia, termasuk perbudakan dan kerja paksa, korban kekerasan, kesewenang-wenangan, kejahatan atas harkat dan martabat manusia serta perlakuan lain yang melanggar hak asasi manusia. Oleh karena itu negara wajib menjamin dan melindungi hak asasi warga negaranya yang bekerja baik di dalam maupun di luar negeri berdasarkan prinsip persamaan hak, demokrasi, keadilan sosial, kesetaraan dan keadilan gender, anti diskriminasi dan anti perdagangan manusia.(Astawa, 2006: 3)

Naovalita mengidentifikasi ada beberapa permasalahan klasik yang menimpa TKI di luar negeri, yaitu:

1. Pada tahap pra-penempatan, bentuk ancaman eksploitasi antara lain mencakup pemerasan, penipuan baik oleh calo, sponsor maupun agen perekrut, dikurung di tempat penampungan, tinggal di tempat penampungan dengan fasilitas buruk seperti: jumlah orang yang lebih banyak dari pada kapasitas penampungan, fasilitas tempat tidur yang tidak memadai, makanan yang kurang bergizi, fasilitas sanitasi yang tidak memadai, kekerasan seksual dan pemalsuan dokumen;

2. Pada tahap penempatan bentuk ancaman eksploitasi yang dihadapi meliputi: pemerasan oleh agen dan majikan di negara penerima (seperti: gaji yang ditahan, pengurangan jumlah gaji dari yang seharusnya diterima, atau gaji yang dibayar sangat rendah), pemutusan kontrak, beban kerja yang berlebihan (lebih dari 10 jam sehari), tidak diizinkan untuk berkomunikasi dengan keluarga atau sesama buruh migran, kekerasan psikologis, kekerasan fisik bahkan kekerasan seksual;

3. Adapun pada tahap purna penempatan, bentuk ancaman eksploitasi berupa pemerasan yang dilakukan pihak-pihak tertentu di Bandara Soekarno-Hatta maupun pemerasan oleh supir kendaraan dalam perjalanan pulang ke daerah asal. Buruh migran juga di paksa untuk menukarkan mata uang asing yang mereka bawa ke dalam rupiah dengan nilai tukar yang sangat rendah. Pada tingkatan rumah tangga, uang yang di hasilkan pun tidak terlepas dari ancaman penyalahgunaan oleh suami atau oleh anggota keluarga lainnya".(Naovalita, dkk., 2006: 64-65)

Terbitnya Undang-Undang Nomor 39 Tahun 2004 tentang Penempatan dan Perlindungan TKI di Luar Negeri merupakan salah satu bentuk perlindungan hukum kepada TKI yang sering sekali menghadapi berbagai persoalan hukum seperti kekerasan, eksploitasi, dan perlakuan yang bertentangan dengan harkat dan martabat kemanusiaan (other violated human dignity). Hal ini dinyatakan secara eksplisit dalam Undang-undang Nomor 39 Tahun 2004 sebagaimana disebutkan pada bagian konsideran menimbangnya "bahwa bekerja merupakan hak asasi manusia yang wajib dijunjung tinggi, dihormati, dan dijamin penegakannya". (Husni, 2011:4)

Artinya bahwa meskipun bekerja di luar negeri, pemerintah tetap memiliki kewajiban untuk melindungi warga negaranya dari perlakuan sewenang-wenang dari orang/warga negara lain, walaupun warga negara itu bekerja di negara lain. Pembiaran terhadap seorang warga negara yang diperlukan tidak adil, merupakan penghianatan terhadap hak-hak warga negara.

\section{Peran Negara dalam Perlindungan Hukum Tenaga Kerja Indonesia yang Bermasalah di Luar Negeri}

Budiardjo mengatakan bahwa tujuan negara untuk menyelenggarakan beberapa minimum fungsi yang mutlak perlu, yakni: 
DEIEGA LATA

Jurnal Ilmu Hukum

FAKULTAS HUKUM UMSU
Peran dan Tanggung.Jawab Negara...(Ida Hanifah)

Volume 5 Nomor 1, Januari - Juni 2020, 10-23 DOI: htps://doi.org/10.30596/dll.v5i1.3303

1. Melaksanakan penertiban (law and order), untuk mencapai tujuan bersama dan mencegah bentrokan-bentrokan dalam masyarakat, maka negara harus melaksanakan penertiban. Dapat dikatakan bahwa negara bertindak sebagai stabilisator;

2. Mengusahakan kesejahteraan dan kemakmuran seluruh rakyat. Fungsi ini sangat mengedepan terutama bagi negara-negara baru;

3. Pertahanan, hal ini diperlukan untuk menjaga kemungkinan serangan dari luar. Untuk ini negara dilengkapi dengan alat-alat pertahanan;

4. Menegakkan keadilan, hal ini dilaksanakan melalui badan-badan pengadilan.(Budiardjo, 2001: 39-46)

Tujuan negara Republik Indonesia tercantum dalam alinea ke-4 Pembukaan UUD 1945 adalah :

Kemudian daripada itu untuk membentuk suatu Pemerintah Negara Indonesia yang melindungi segenap bangsa Indonesia dan seluruh tumpah darah Indonesia dan untuk memajukan kesejahteraan umum, mencerdaskan kehidupan bangsa dan ikut melaksanakan ketertiban dunia yang berdasarkan kemerdekaan, perdamaian abadi dan keadilan sosial, maka disusunlah Kemerdekaan Kebangsaan Indonesia itu dalam suatu Undang-Undang Dasar Negara Indonesia yang terbentuk dalam suatu susunan Negara Republik Indonesia yang berkedaulatan rakyat dengan berdasarkan kepada Ketuhanan Yang Maha Esa, Kemanusiaan yang adil dan beradab, Persatuan Indonesia dan Kerakyatan yang dipimpin oleh hikmat kebijaksanaan dalam Permusyawaratan/Perwakilan serta dengan mewujudkan suatu Keadilan sosial bagi seluruh rakyat Indonesia.

Semua fungsi negara diatas yang mesti diwujudkan oleh pemerintah untuk tercapainya tujuan yang sudah ditetapkan dalam rangka mewujudkan kesejahteraan bagi seluruh rakyat tanpa terkecuali. Eksistensi sebuah pemerintahan sebenarnya dipertaruhkan apabila hak-hak warga negara yang bekerja di luar negeri terabaikan dan tanpa perlindungan. Oleh karena (Zainuddin) itu negara dalam hal ini memiliki kewenangan terhadap penyelenggaraan pemerintahan yang berasal dari peraturan perundang-undangan (2019, h. 275).

Pemberian perlindungan oleh Negara kepada rakyatnya merupakan kewajiban sebagaimana yang diamanatkan oleh konstitusi, dalam pembukaan Undang-undang Dasar Negara tahun 1945, alinea ke-empat. Kalimat "melindungi segenap bangsa Indonesia" bermakna dan memberikan pengertian yang mendalam, arti melindungi berarti ada upaya untuk memberikan perlindungan terhadap individu warganegara dalam segenap aspek kehidupan dari berbagai upaya penindasan maupun eksploitasi semena-mena dari pihak lain, sedangkan pengertian perlindungan adalah menjaga dan memberikan kesempatan seluas-luasnya untuk memperoleh kehidupan dan penghidupan layak sebagai manusia. (Sukomono, 2017: 57)

Peran penting pemerintah baik pusat maupun daerah dalam perlindungan TKI di luar negeri yakni: pertama, Negara wajib melindungi setiap warga negaranya dimanapun mereka berada dan apapun yang mereka kerjakan. Dalam Pasal 18 UU Nomor 37 Tahun 1999 tentang Hubungan Luar Negeri, Pemerintah Republik Indonesia wajib melindungi kepentingan warga negara atau badan hukum Indonesia yang menghadapi permasalahan hukum dengan perwakilan negara asing di Indonesia. Pada Pasal 19b menyatakan Perwakilan RI berkewajiban untuk memberikan pengayoman, perlindungan, dan bantuan hukum bagi warga negara dan badan hukum Indonesia di luar negeri. (Ferricha, 2016: 145) 


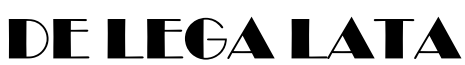

Jurnal Ilmu Hukum

FAKULTAS HUKUM UMSU
Peran dan Tanggung.Jawab Negara...(Ida Hanifah) Volume 5 Nomor 1, Januari - Juni 2020, 10-23 DOI: https://doi.org/10.30596/dll.v5i1.3303

Menurut Andriyeni, dkk., ternyata kehadiran UU No. 39 Tahun 2004 tentang Penempatan dan Perlindungan Tenaga Kerja Indonesia di Luar Negeri merupakan contoh nyata Negara tidak menjalankan kewajibannya memenuhi, melindungi, dan menghormati hak-hak buruh migran yang bekerja di luar negeri. Melalui kebijakan ini, peran pemerintah direduksi, dan hak warga Negara diubah menjadi komoditas. UU ini menyerahkan peran-peran penting yang merupakan kewajiban Negara, seperti perekrutan, pendidikan, pelatihan, tes kesehatan dan pelayanan kesehatan, maupun penempatan buruh migran kepada pihak swasta. (Andryeni, dkk, 2015: 15)

Tenaga kerja Indonesia terutama buruh migran perempuan, yang bekerja sebaga pembantu rumah tangga (PRT) secara sistemik dibuat menjadi tergantung terhadap calo, PPTKIS, Klinik swasta, agen perekrutan, dan perusahaan asuransi di setiap tahapan migrasi. Tidak adanya mekanisme pengawasan pemerintah yang memadai secara tegas merupakan bentuk pengabaian pemerintah dalam melindungi warga negaranya yang bekerja sebagai buruh migran.(Andryeni, dkk., 2015: 15)

Secara lebih spesifik, Undang-Undang Nomor 39 Tahun 2004 tentang Penempatan dan Perlindungan Tenaga Kerja Indonesia di luar negeri yang disahkan pada 28 Oktober 2004 ini teryata lebih banyak mengatur mengenai penempatan Buruh Migran daripada mengatur aspek perlindungannya. Dalam UU tersebut terdapat 16 Bab dan 109 Pasal, pengaturan mengenai perlindungan hanya terdapat dalam 1 Bab yang terdiri dari 8 Pasal dan 14 ayat. Bab mengenai pelaksanaan penempatan terdiri dari 17 pasal dan 35 ayat, sementara itu sebanyak 50 pasal dan 96 ayat berbicara mengenai tata cara penempatan.

Bukan hanya itu nilai minusnya, UU No. 39 Tahun 2004 telah membatasi perlindungan hanya untuk buruh migran yang memenuhi syarat untuk bekerja di luar negeri. Salah satu dari syarat tersebut adalah berdokumen. Padahal, kewajiban Negara atas perlindungan TKI berlaku bagi seluruh TKI tanpa melihat status dokumen mereka. Berdokumen ataupun tidak berdokumen, mereka adalah warga Negara yang memiliki sejumlah hak yang harus dipenuhi, dilindungi, dan dihormati oleh Negara. (Andryeni, dkk., 2015: 16)

Fakta lain yang menjadikan peran Negara menjadi kurang maksimal dalam upaya perlindungan hukum terhadap TKI adalah persoalan klasik yaitu tumpang tindihnya peran dan fungsi berbagai instansi yang terlibat dalam proses migrasi (BNP2TKI dan Kemenakertrans), lemahnya penegakan hukum untuk persoalan-persoalan yang terjadi dalam setiap proses migrasi, tidak adanya satu sistem yang mempersatukan berbagai peran dan fungsi berbagai instansi yang terlibat dalam satu mekanisme yang telah teratur.(Krustiyati, 2013: 138)

Urgensi kehadiran negara dalam setiap perlindungan hukum bagi TKI yang bekerja di luar negeri juga diperlukan mengingat sistem hukum yang berbeda antara yang berlaku di Indonesia dengan yang berlaku di negara dimana TKI tersebut bekerja. Berdasarkan kondisi tersebut, maka perlu adanya Memorandum of Understanding (MoU) antara Indonesia dengan sebuah negara apabila terjadi hubungan hukum antara TKI yang berasal dari Indonesia dengan majikan disebuah negara.

Berkaitan dengan hubungan kerja, yang subjek hukumnya sama-sama warga negara suatu negara dan berdomisili di wilayah negara tempat mereka menjadi warga negara, maka hubungan kerja antara pekerja dan majikan sebagai subjek hukum dalam hubungan kerja tersebut akan tunduk pada aturan hukum hubungan kerja yang sama. Untuk hubungan kerja yang subjek hukumnya berkewarganegaraan berbedaseperti misalnya antara tenaga kerja E-ISSN: 2477-7889 I ISSN: 2477-653XXI URL: http://jurnal.umsu.ac.id/index.php/delegalata 


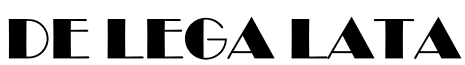

Jurnal Ilmu Hukum

FAKULTAS HUKUM UMSU
Peran dan TanggungJawab Negara...(Ida Hanifah) Volume 5 Nomor 1, Januari - Juni 2020, 10-23 DOI: https://doi.org/10.30596/dll.v5i1.3303

Indonesia (TKI) di luar negeri dengan majikannya di negara penempatan, tentu akan tunduk pada hukum negara tempat TKI ditempatkan kecuali jika telah terdapat kerja sama bilateral antara Indonesia dengan negara penempatan TKI yang mengatur dengan lengkap mengenai hubungan kerja tersebut.(Sumiyati, 2013: 53)

Pada Undang-Undang Nomor 39 Tahun 2004 tentang Penempatan dan Perlindungan Tenga Kerja Indonesia di Luar Negeri pada Pasal 5 ayat (1) tentang tugas, tanggung jawab dan Kewajiban Pemerintah dijelaskan bahwa penyelenggaraan penempatan dan perlindungan TKI diluar negeri dilakukan secara seimbang oleh pemerintah dan masyarakat. Agar penyelenggaraan dan penempatan dan perlindungan TKI diluar negeri tersebut dapat berhasil guna dan berdaya guna pemerintah perlu mengatur, membina, dan mengawasi pelaksanaannya. Pada Pasal 6 juga dijelaskan bahwa pemerintah bertanggung jawab untuk meningkatkan upaya perlindungan TKI diluar Negeri.(Sumardiani, 2014: 256)

Peran serta Negara terhadap TKIsangatlah penting. Deskripsi utuh untuk melihat peran Negara sejauh ini hanya dilihat dari bentuk peraturan perundang-undangan yang dikeluarkan sebagai respon terhadap kebutuhan Tenaga Kerja Indonesia yang bekerja di luar negeri. Indikator atas kondisi perlindungan terhadap TKI setidaknya dapat dilihat dari 3 (tiga) aspek yaitu pra penempatan, penempatan dan purna penempatan. Ketiga aspek tersebut hanya sekedar merefleksikan bagaimana perlindungan terhadap TKI. Sebaiknya memang penempatan dan perlindungan TKI adalah hal yang saling terkait satu sama lain. Intinya tidak ada penempatan jika tidak diiringi dengan perlindungan dan perlindungan ini adalah bagian dari penempatan. (Sumardiani, 2014: 256)

\section{Tanggungjawab Negara dalam Perlindungan Hukum Tenaga Kerja Indonesia yang Bermasalah di Luar Negeri}

Makna dan arti pentingnya pekerjaan bagi setiap orang tercermin dalam Pasal 27 ayat (2) Undang-Undang Dasar tahun 1945. Berdasarkan konsideran Pasal 27 ayat (2) tersebut, maka setiap warga negara berhak untuk memilih, mendapatkan atau pindah pekerjaan dan memperoleh penghasilan yang layak di dalam atau di luar negeri, telah dijamin melalui Pasal 31 Undang-UndangNomor 13 Tahun tentang 2003 tentang Ketenagakerjaan. Penempatan tenaga kerja keluar negeri diarahkan untuk menempatkan tenaga kerja pada jabatan yang tepat sesuai dengan keahlian, keterampilan, bakat, minat, dan kemampuan dengan memerhatikan harkat, martabat, hak asasi, dan perlindungan hukum. (Pasal 32 ayat (2) UU Ketenagakerjaan).(Adharinalti, 2012: 158)

Keterbatasan lapangan kerja dalam ranah domestik, membuat banyak pekerja Indonesia memilih luar negeri untuk mencari penghidupan yang layak. Dengan keberadaan warga Negara yang bekerja diluar negeri tersebut membuat pemerintah Indonesia berkewajiban untuk melindungi warga negaranya yang berada di luar negeri itu. Dalam melindungi TKI yang berada di luar negeri tersebut negara dihadapkan pada permasalahan antara kepentingan untukmelindungi warga Negara yang berada di luar negeri dengan hukum yang berlaku di Negara tempat warga Negara Indonesia tersebut berada. (Arpangi, 2016: 152)

Pemberian perlindungan hukum bagi warga negara Indonesia dalam hal ini TKI merupakan salah satu tugas pokok perwakilan Republik Indonesia di luar negeri sesuai dengan amanat yang tertuang dalam Undang-Undang Dasar 1945 dan Undang-Undang Nomor 37 


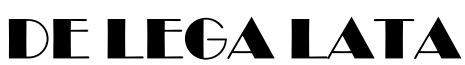

Jurnal Ilmu Hukum

FAKULTAS HUKUM UMSU
Peran dan Tanggung.Jawab Negara...(Ida Hanifah) Volume 5 Nomor 1, Januari - Juni 2020, 10-23 DOI: https://doi.org/10.30596/dll.v5i1.3303

Tahun 1999 tentang Hubungan Luar Negeri. Perlindungan kepada warga negara Indonesia yang berada di luar negeri ini, termasuk pemberian bantuan dan penyuluhan hukum serta pelayanan konsuler (Bab V Pasal 18-24 UU Hubungan Luar Negeri). (Arpangi, 2016: 163)

Asas hukum yang dapat dijadikan landasan filosofis dalam undang-undang penempatan dan perlindungan TKI di Luar Negeri adalah asas tanggung jawab negara (state responsibility). Asas tanggung jawab ini sesuai dengan amanat Pasal 28I ayat 4 UUD Negara Republik Indonesia Tahun 1945 bahwa "Tanggung jawab negara untuk perlindungan, pemajuan, penegakan dan pemenuhan HAM". Tanggung jawab negara di bidang penempatan dan perlindungan TKI yang bekerja di luar negeri berdasarkan Undang-undang Nomor 39 Tahun 2004 diatur dalam Pasal 6 yang menyebutkan bahwa "Pemerintah bertanggungjawab untuk meningkatkan upaya perlindungan TKI di luar negeri". "Dalam melaksanakan tugas dan tanggung jawab tersebut pemerintah berkewajiban memberikan perlindungan kepada TKI selama masa sebelum pemberangkatan, masa penempatan, dan masa purna penempatan" (Pasal 7 huruf e). Meskipun telah diatur, namun dalam pasal-pasal berikutnya dari Undang-undang Nomor 39 Tahun 2004 tidak mengatur lebih lanjut bagaimana bentuk perlindungan tersebut khususnya pada tahap pra penempatan dan setelah penempatan. (Husni, 2011: 23)

Secara filsafat tanggung jawab negara dapat ditemukan pada tujuan bernegara suatu negara. Tujuan bernegara bangsa Indonesia ditemukan pada alinea keempat pembukaan UUD 1945 yakni tidak hanya melindungi warga negara tetapi juga mewujudkan kesejahteraan umum (public welfare), tujuan bernegara seperti ini disebut juga dengan negara hukum kesejahteraan (walfare state). Tanggung jawab negara itu dimaksudkan untuk menjamin hak-hak warga negara atas kehidupan yang layak sebagai manusia, dikemukakan oleh Toshiro Fuke sebagai berikut"The state now assuming the general mandate to secure for citizen their individual right to a life worthy of a human being. (Fuke, 1999: 1)

Konsep tanggung jawab (responsibility) memiliki makna tidak hanya berupa kewajiban (obligation) untuk memenuhi apa yang pernah dilakukan terkait dengan keputusan, keahlian, dan kemampuan seseorang, tetapi juga kemampuan untuk memulihkan (restitution) terhadap kerugian yang dilakukan. Artinya bahwaresponsibility tidak hanya meliputi tanggung jawab hukum, tetapi juga tanggung jawab moral. Dengan demikian tanggung jawab tidak dapat dilepaskan dari makna kewajiban, karena itu kata tanggung jawab sering diartikan sama atau dipertukarkan penggunaannya dengan istilah kewajiban. (Husni, 2011:24)

Pemberian perlindungan kepada TKI di luar negeri diperlukan koordinasi lintas sektoral yang melibatkan peran serta para pemangku kepentingan baik di dalam maupun luar negeri. Tanpa adanya kerjasama dengan instansi dan pihak-pihak terkait, maka pelaksanaan tugastugas pokok tersebut sulit dilaksanakan secara optimal. Untuk dalam negeri, harus ada koordinasi yang erat antara Kemenakertrans, Kementerian Luar Negeri, Pemerintah Daerah, Keimigrasian, Badan Nasional Penempatan dan Perlindungan Tenaga Kerja di Indonesia (BNP2TKI), aparat penegak hukum dan instansi teknis lainnya. Untuk lembaga swasta adalah Pelaksana Penempatan TKI Swasta (PPTKIS) beserta jaringan rekruternya serta organisasi kemasyarakatan dan lembaga swadaya masyarakat. (Adharinalti, 2012: 162)

Lembaga-lembaga di luar negeri yang ikut bertanggungjawab terhadap perlindungan TKI antara lain Perwakilan RI, Perwakilan Pelaksana Penempatan TKI Swasta, Mitra Usaha Pelaksana Penempatan TKI, pengguna jasa TKI, dan instansi resmi yang berwenang dibidang E-ISSN: 2477-7889 I ISSN: 2477-653XI URL: http://jurnal.umsu.ac.id/index.php/delegalata 
DEIEGA LATA

Jurnal Ilmu Hukum

FAKULTAS HUKUM UMSU
Peran dan Tanggung.Jawab Negara...(Ida Hanifah)

Volume 5 Nomor 1, Januari - Juni 2020, 10-23 DOI: https://doi.org/10.30596/dll.v5i1.3303

ketenagakerjaan di negara penerima, juga lembaga/organisasi resmi seperti Badan Perserikatan Bangsa-Bangsa yang berkompeten di bidang ketenagakerjaan atau hak asasi manusia serta Non Government Organization (NGO) yang bergerak dibidang ketenagakerjaan/Hak Asasi Manusia (HAM). (Adharinalti, 2012: 163)

Negara dalam hal ini pemerintah berkewajiban memberikan dukungan fasilitas yang dituangkan dalam program-program peningkatan kualitas tenaga kerja di Indonesia. Programprogram tersebut, misalnya kursus bahasa dimana TKI tersebut akan ditempatkan, program pelatihan skil dan kemampuan profesional sesuai dengan pekerjaan yang diinginkan, serta mempelajari kultur negara tujuan TKI.

Tanggungjawab dan kewajiban pemerintah Indonesia merupakan implementasi dari pelaksanaan perlindungan hak asasi manusia terhadap hak-hak TKI, khususnya di dibidang ketenagakerjaan, termasuk tenaga kerja Indonesia di luar negeri yang cukup rentan terhadap pelanggaran hak asasi manusia.(Gunawan, 2015: 174)

Tanggungjawab dan Kewajiban Pemerintah Indonesia telah diatur dalam BAB II Undang-undang Nomor 39 Tahun 2004 tentang Penempatan dan Perlindungan Tenaga Kerja Indonesia di Luar Negeri diatur mengenai tugas, tanggung jawab, dan kewajiban pemerintah. Dalam Pasal 5 dinyatakan bahwa:

1. Pemerintah bertugas mengatur, membina, melaksanakan, dan mengawasi penyelenggaraan penempatan dan perlindungan TKI di luar negeri.

2. Dalam melaksanakan tugas sebagaimana dimaksud pada ayat (1), Pemerintah dapat melimpahkan sebagian wewenangnya dan/atau tugas perbantuan kepada pemerintah daerah sesuai dengan peraturan perundang-undangan.

Pasal 6 menyatakan bahwa pemerintah bertanggung jawab untuk meningkatkan upaya perlindungan TKI di luar negeri. Pasal 7 menyatakan bahwa: "dalam melaksanakan tugas dan tanggung jawab sebagaimana dimaksud dalam Pasal 5 dan Pasal 6 Pemerintah berkewajiban:

1. Menjamin terpenuhinya hak-hak calon TKI/TKI, baik yang berangkat melalui pelaksana penempatan TKI, maupun yang berangkat secara mandiri;

2. Mengawasi pelaksanaan penempatan calon TKI;

3. membentuk dan mengembangkan sistem informasi penempatan calon TKI di luar negeri;

4. Melakukan upaya diplomatik untuk menjamin pemenuhan hak dan perlindungan TKI secara optimal di negara tujuan; dan

5. Memberikan perlindungan kepada TKI selama masa sebelum pemberangkatan, masa penempatan, dan masa purna penempatan.

Perlindungan hukum terhadap TKI yang bekerja di luar negeri juga terkait dengan hubungan politik dan diplomasi yang harus dilakukan oleh pemerintah negara yang menjadi tempat TKI tersebut bekerja. Kasus terlantarnya ribuan TKI di kolong jembatan Kandara Arab Saudi, seharusnya menjadi pelajaran penting bagi pemerintah Indonesia untuk lebih optimal melindungi TKI.

Permasalahan TKI yang berada di kolong jembatan Kandara dari sisi pemerintan Indonesia menyebutkan bahwa kasus tersebut dikarenakan TKI tersebut kehabisan izin tinggalnya. Penjelasan berbeda justru sangat berbeda dengan apa yang diberitakan di berbagai mas media, karena dari permasalahan TKI tersebut ternyata banyak juga TKI tersebut pergi dari 
DE LEGA LATA

Jurnal Ilmu Hukum

FAKULTAS HUKUM UMSU
Peran dan Tanggung.Jawab Negara...(Ida Hanifah)

Volume 5 Nomor 1, Januari - Juni 2020, 10-23 DOI: https://doi.org/10.30596/dll.v5i1.3303

rumah sang majikan. Hal itu terjadi dikarenakan TKI tersebut mendapatkan perlakuan yang tidak sebagaimana mestinya oleh sang majikan, seperti pelecehan sex, perlakuan kasar bahkan penyiksaan dan lain sebagainya. (Arpangi, 2016: 153)

Berdasarkan kasus tersebut ternyata pemerintah Indonesia tidak mampu untuk memulangkan para TKI yang hidup terlunta-lunta di negeri orang tersebut. Kejadian tersebut seharusnya tidak terjadi kalau antara pemerintah Indonesia dengan pemerintah Arab Saudi saling meningkatkan hubungan diplomatiknya dan mau melihat kembali MoU yang telah disepakati bersama. Apabila Mou tersebut sudah tidak relevan lagi dan perlu untuk diadakan peninjauan kembali maka secepatnya untuk bisa merevisi Mou tersebut, sehingga TKI yang berada di Arab Saudi tersebut bisa mendapatkan perlindungan secara maksimal.

Model diplomasi perlindungan Pemerintah Indonesia terhadap WNI di luar negeri lebih diprioritaskan pada upaya perlindungan secara hukum, dengan kata lain ketika WNI mengalami suatu permasalahan atau kasus, pihak pemerintah Indonesia melakukan pendampingan dan perlindungan secara hukum sebagaimana panduan hukum yang dijadikan acuan dalam prosesnya selama ini dan pemerintah Indonesia bukan sebagai pihak yang menerima hukuman atas setiap kasus atau pelanggaran yang dilakukan oleh WNI. Saat ini pemetaan diplomasiperlindungan pemerintah Indonesia lebih banyak untuk kasus-kasus seperti Overstayer dan kasus TKI Undocumented.(Paramitaningrum, dkk., 2018: 35-36)

Tanpa adanya diplomasi tersebut, maka dapat dipastikan negara-negara yang menjadi destinasi TKI tersebut akan menganggap remeh kepada TKI, karena masyarakat negara-negara penerima TKI akan memandang bahwa orang Indonesia adalah sangat rendah, dan bisa saja disamakan dengan gelandangan, sehingga mereka akan memperlakukan para TKI tersebut seenaknya sendiri ibaratnya gelandanggan atau bahkan lebih hina lagi disamakan dengan budak pada zaman dulu.

Sesuai dengan asas hukum internasional perlindungan hukum terhadap warga negara berhenti pada saat warga negara tersebut melewati batas wilayah jurisdiksi negara. Perlindungan terhadap tenaga kerja Indonesia di luar negeri atau dinegara penerima dilakukan sesuai dengan hukum internasional dan hukum yang berlaku di negara tersebut. Bentuk intervensi negara yang diakui oleh hukum internasional adalah P1, CA, DP.(Arpangi, 2016: 2016)

\section{KESIMPULAN}

Peran penting pemerintah baik pusat maupun daerah dalam perlindungan TKI di luar negeri yakni: pertama, Negara wajib melindungi setiap warga negaranya dimanapun mereka berada dan apapun yang mereka kerjakan. Sedangkan Tanggung jawab negara dapat ditemukan pada tujuan bernegara sebagaimana tercantum dalam alinea keempat pembukaan UUD 1945 yakni tidak hanya melindungi warga negara tetapi juga mewujudkan kesejahteraan umum (public welfare), tujuan bernegara seperti ini disebut juga dengan negara hukum kesejahteraan (walfare state).

\section{SARAN}

Masih banyaknya kasus-kasus hukum maupun kasus lainnya yang menimpa TKI yang bekerja di luar negeri, menyuratkan sebuah simpulan bahwa peran dan tanggungjawab negara 
DE LEGA LATA

Jurnal Ilmu Hukum

FAKULTAS HUKUM UMSU
Peran dan TanggungJawab Negara...(Ida Hanifah)

Volume 5 Nomor 1, Januari - Juni 2020, 10-23 DOI: https://doi.org/10.30596/dll.v5i1.3303

dalam hal ini pemerintah, masih belum optimal. Berdasarkan kondisi tersebut, maka baik DPR maupun Pemerintah serta lembaga-lembaga terkait dengan penempatan TKI di luar negeri perlu untuk duduk bersama menyelesaikan serta mencari formula yang tepat untuk melindungi nasib para pahlawan devisa negara itu. Apabila memang diperlukan berbagai regulasi yang kurang bersahabat dengan perlindungan terhadap TKI di luar negari agar direvisi, atau bahkan diganti dengan yang lebih baik lagi. 


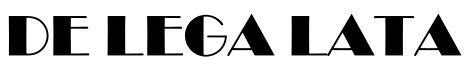

Jurnal Ilmu Hukum

FAKULTAS HUKUM UMSU
Peran dan Tanggung.Jawab Negara...(Ida Hanifah)

Volume 5 Nomor 1, Januari - Juni 2020, 10-23 DOI: https://doi.org/10.30596/dll.v5i1.3303

\section{DAFTAR PUSTAKA}

Adharinalti, "Perlindungan Terhadap Tenaga Kerja Indonesia Irregular Di Luar Negeri", dalam Jurnal Rechtsvinding Media Pembinaan Hukum Nasional, Vol. 1, No. 1, April 2012.

Ahmad Firdaus Sukomono, "Perlindungan Tenaga Kerja Indonesia di Luar Negeri Melalui Sertifikasi Kompetensi”, dalam Jurnal Dialogia Iuridica: Jurnal Hukum Bisnis dan Investasi, Volume 8 Nomor 2 April 2017, Bandung: Fakultas Hukum Universitas Kristen Maranatha.

Andriyeni, Dinda Nuuraannisaa Yura, Ratih Putri Budiyanti. 2015. Menggugat Tanggung Jawab Negara Atas Perlindungan Buruh Migran Perempuan Dan Anggota Keluarganya Catatan Penanganan Kasus Solidaritas Perempuan Februari 2012 - Februari 2015, Jakarta: Solidaritas Perempuan.

Arpangi, "Perlindungan Hukum Terhadap Tenaga Kerja Indonesia Di Luar Negeri”, dalam Jurnal Pembaharuan Hukum, Volume III, No. 1, Januari-April 2016

Atik Krustiyati, "Optimalisasi Perlindungan Dan Bantuan Hukum Pekerja Migran Melalui Promosi Konvensi Pekerja Migran Tahun 2000", dalam Jurnal Dinamika Hukum, Vol. 13, No. 1, Tahun 2013.

Dewa Rai Astawa, “Aspek Perlindungan Hukum Hak-Hak Tenaga Kerja Indonesia Di Luar Negeri”. Tesis. 2006. Semarang: Program Magister Ilmu Hukum Universitas Diponegoro.

Dian Ferricha, "Tanggung Jawab Pemerintah Daerah Pada Penempatan Dan Perlindungan Tenaga Kerja Indonesia Menuju Negara Kesejahteraan”, dalam Jurnal Ahkam, Volume 4, Nomor 1, Juli 2016.

Fenny Sumardiani, "Peran Serikat Buruh Migran Indonesia dalam Melindungi Hak Tenaga Kerja Indonesia di Luar Negeri”, dalam Jurnal Pandecta, Vol. 9, No. 2, Januari 2014.

Gloria Gunawan, "Perlindungan Hukum Terhadap Tenaga Kerja Indonesia Di Luar Negeri" dalam Jurnal Lex Privatum, Vol. III, No. 2, April- Juni 2015.

Istanto, F.S., Penelitian Hukum, CV. Ganda, Yogyakarta, 2007.

Lalu Husni, "Penempatan Dan Perlindungan Hukum Terhadap Tenaga Kerja Indonesia Yang Bekerja Di Luar Negeri (Kajian Yuridis Terhadap Asas Hukum dalam Undang-undang Nomor 39 Tahun 2004 Guna Mewujudkan Penempatan \& Perlindungan TKI yang Bermartabat)", dalam Jurnal Ilmu Hukum, Vol. 14, No. 1, Maret 2011.

Marzuki, P.M., Penelitian Hukum, Kencana Prenada Media Group, Jakarta, 2005.

Mega Putra Ratya, melalui HYPERLINK "http://www.detikNews.com" www.detikNews.com, diakses tanggal 23 September 2018.

Miriam Budiardjo, 2001. Dasar-Dasar Ilmu Politik. Jakarta: Gramedia Pustaka Utama.

Paramitaningrum, Richa V. Yustikaningrum, Galuh Dian Prama Dewi, "Model Diplomasi Perlindungan Pemerintah Indonesia terhadap Warga Negara Indonesia Pekerja Sektor Formal dan Informal di Luar Negeri” dalam Jurnal Global \& Strategis, Th. 12, No. 1, Januari - Juni 2018.

Ramadhani, Rahmat. (2017). Jaminan Kepastian Hukum Yang Terkandung Dalam Sertipikat Hak Atas Tanah, 2, (1), 139-156. https://doi.org/10.30596/dll.v2i1.1144

Republik Indonesia Undang-Undang Nomor 37 Tahun 1999 tentang Hubungan Luar Negeri

Republik Indonesia Undang-Undang Dasar Negara Republik Indonesia Tahun 1945. 
DE LEGA LATA

Jurnal Ilmu Hukum

FAKULTAS HUKUM UMSU
Peran dan Tanggung.Jawab Negara...(Ida Hanifah)

Volume 5 Nomor 1, Januari - Juni 2020, 10-23 DOI: https://doi.org/10.30596/dll.v5i1.3303

Republik Indonesia Undang-undang Nomor 39 Tahun 2004 tentang Penempatan dan Perlindungan Tenaga Kerja Indonesia di Luar Negeri.

Sari Zunairah Ashleena, "Masihkah Pemerintah Peduli akan Nasib Buruh Migran Indonesia?", melalui https://www.muslimahnews.com/2018/04/16/masihkah-pemerintah-peduli-akannasib-buruh-migran-indonesia-2/, diakses tanggal 28 September 2018.

Sumiyati, "Perlindungan Hukum Bagi Pekerja Migran Indonesia Di Luar Negeri Akibat Pemutusan Hubungan Kerja Sepihak", dalam Jurnal Sigma-Mu,Vol. 5 No. 1 - Maret 2013.

Tita Naovalita dkk, "Perlindungan Sosial Buruh Migran Perempuan", Proseding Seminar, The world Bank bekerjasama dengan Kementerian Kesejahteraan Rakyat RI, Jakarta, 2-3 Mei 2006.

Toshiro Fuke, 1999, Comparative Studies on Governmental Liability in East and Southeast Asia, Kluwer Law International London/Boston.

Yuli Yanna Fauzie, "Bank Dunia: Remitansi TKI Tembus Rp118 Triliun", melalui https://www.cnnindonesia.com/ekonomi/20171128114247-78-258562/bank-duniaremitansi-tki-tembus-rp118-triliun, diakses tanggal 25 September 2018.

Zainuddin. (2019). Eksekusi Terhadap Pembatalan Surat Izin Mendirikan Bangunan Pada Perkara Tata Usaha Negara, 4, (2), 271-288. https://doi.org/10.30596/dll.v4i2.3198. 